\title{
Monitoring BK virus infection in pediatric kidney transplant recipients
}

\author{
Min Hyun Cho, MD \\ Department of Pediatrics, Kyungpook National University Hospital, School of Medicine, Kyungpook National University, Daegu, Korea
}

Polyomavirus BK (BKV) is an important cause of allograft dysfunction and graft loss in kidney transplant recipients. ${ }^{1,2)}$ The clinical manifestations of BKV infection, including $\mathrm{BK}$ viuria, BK viremia, and BKV nephropathy (BKVN), commonly develop during the first posttransplantation year. ${ }^{1)} \mathrm{BK}$ viremia is very common in children after kidney transplantation, especially in younger children and those receiving a kidney from a cadaveric donor. ${ }^{3)} \mathrm{BKV}$ infection can be diagnosed via the detection of decoy cells in urine cytology, confirming the presence of Haufen, which are icosahedral aggregates of polyomavirus particles by electron microscopy, and the detection of BKV DNA using urine and blood polymerase chain reaction (PCR) assays. Among them, measuring BKV DNA load in the blood using PCR is considered the preferred method of diagnosing BKV infection due its higher sensitivity and specificity as well as cost-effectiveness than other methods such as urine PCR and decoy cells. ${ }^{4)}$ The diagnosis of BKVN is made by allograft biopsy, which shows tubulointerstitial mononuclear infiltration with many plasma cells, degenerative changes in the tubules, and intranuclear polyomavirus inclusion via SV40 immunoperoxidase stain.

Many studies reported that routine monitoring of BKV reactivation and adequate reduction of immunosuppression alone can effectively resolve viremia, preserve allograft function, and prevent symptomatic BKVN. Kwon et al. ${ }^{5)}$ also reported that BKV infection developed in nine of 33 pediatric kidney transplant recipients (27.3\%) and was effectively resolved by reduction of calcineurin inhibitor via routine monitoring of BKV load. Although there are several anti-BKV agents such as leflunomide, cidofovir, intravenous immunoglobulin, and fluoroquinolone, the benefit of these agents is limited. ${ }^{1)}$ Therefore, the preemptive approach to resolving BKV viuria and/or viremia before the development of BKVN with reduction of immunosuppression is the mainstay of therapy in BK viremia/BKVN. ${ }^{6}$ The 2009 Kidney Disease: Improving Global Outcomes clinical practice guidelines recommend reducing immunosuppression when BKV plasma nucleic acid testing results are persistently greater than $10^{4}$ copies $/ \mathrm{mL}$.

According to clinical algorithm based on current guidelines and available evidence (Fig. 1), screening for BK virus reactivation is recommended at least monthly for the first 3-6 months after kidney transplantation ${ }^{7)}$ and then every 3 months until the end of the first posttransplantation year. This is also recommended in cases of an unexplained rise in serum creatinine or after the treatment of acute rejection. If a patient presents with elevated serum creatinine and significant viremia (BK viral load $>10^{4}$ copies/mL on PCR), a graft biopsy should be performed to confirm definitive BKVN. ${ }^{1)}$

There is one thing to consider here. Allograft dysfunction combined with significant BK viremia does not always lead to BKVN. Because it is difficult to exclude the possibility of acute rejection or BKVN combined with acute rejection in such situations, an abrupt reduction in immunosuppression without confirmation of the pathologic findings of definitive BKVN can be counter-productive. Unfortunately, Kwon et al. ${ }^{5)}$ reported that 6 of 9 patients with significant BK viremia presented azotemia, but none underwent renal biopsy, which limited their study. In conclusion, routine screening for BK virus reactivation and active use of graft
Corresponding author: Min Hyun Cho, MD Department of Pediatrics, Kyungpook National University Hospital, School of Medicine, Kyungpook National University, 130 Dongdeok-ro, Jung-gu, Daegu 41944, Korea

Tel: +82-53-420-5719

Fax: +82-53-425-6683

E-mail: chomh@knu.ac.kr

https://orcid.org/0000-0002-7965-7587

Received: 17 September, 2019

Revised: 7 October, 2019

Accepted: 18 October, 2019

See the article "Clinical manifestations of BK virus infection in pediatric kidney transplant patients" in Volume 62 on page 422.

Copyright $@ 2019$ by The Korean Pediatric Society

This is an open-access article distributed under the terms of the Creative Commons Attribution NonCommercial License (http://creativecommons.org/ licenses/by-nc/4.0/ which permits unrestricted noncommercial use, distribution, and reproduction in any medium, provided the original work is properly cited. 
Korean J Pediatr 2019;62(11):414-415

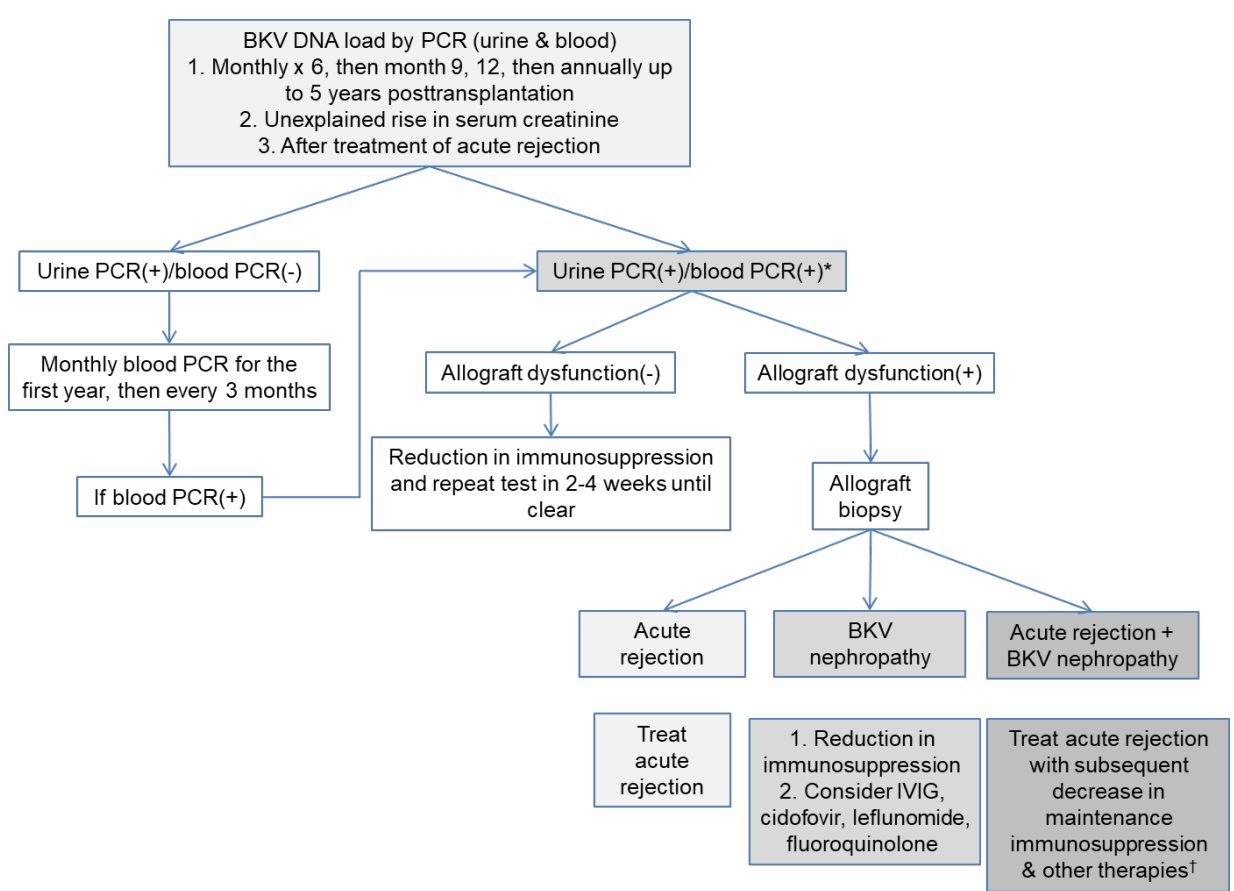

Fig. 1. Clinical algorithm of management of BK virus infection in kidney transplant recipients. *Blood PCR(+): significant viremia (BK viral load $>10^{4}$ copies $/ \mathrm{mL}$ ). ${ }^{\dagger}$ Other therapies: IVIG, cidofovir, leflunomide, and fluoroquinolone, etc. BKV, BK virus; PCR, polymerase chain reaction; IVIG, intravenous immunoglobulin.

biopsy are the most reliable ways to overcome BK virus infection in pediatric kidney transplant recipients.

\section{Conflicts of interest}

No potential conflict of interest relevant to this article was reported.

\section{References}

1. Lamarche C, Orio J, Collette S, Senécal L, Hébert MJ, Renoult É, et al. BK polyomavirus and the transplanted kidney: immunopathology and therapeutic approaches. Transplantation 2016;100:2276-87.

2. Hymes LC, Warshaw BL. Polyomavirus (BK) in pediatric renal transplants: evaluation of viremic patients with and without BK asso- ciated nephritis. Pediatr Transplant 2006;10:920-2.

3. Zarauza Santoveña A, García Meseguer C, Martínez Mejía S, Alonso Melgar Á, Fernández Camblor C, Melgosa Hijosa M, et al. BK virus infection in pediatric renal transplantation. Transplant Proc 2015; 47:62-6.

4. Hirsch HH, Knowles W, Dickenmann M, Passweg J, Klimkait T, Mihatsch MJ, et al. Prospective study of polyomavirus type BK replication and nephropathy in renal-transplant recipients. N Engl J Med 2002;347:488-96.

5. Kwon Y, Kim JY, Lee Y, Cho H. Clinical manifestations of BK virus infection in pediatric kidney transplant patients. Korean J Pediatr 2019;62:422-7.

6. Ginevri F, Azzi A, Hirsch HH, Basso S, Fontana I, Cioni M, et al. Prospective monitoring of polyomavirus BK replication and impact of pre-emptive intervention in pediatric kidney recipients. Am J Transplant 2007;7:2727-35.

7. Alméras C, Vetromile F, Garrigue V, Szwarc I, Foulongne V, Mourad G. Monthly screening for BK viremia is an effective strategy to prevent BK virus nephropathy in renal transplant recipients. Transpl Infect Dis 2011;13:101-8. 